\title{
МЕТОДИЧНІ ПІДХОДИ ТА ІДЕНТИФІКАЦІЯ ТЕРИТОРІЙ ІЗ ОСОБЛИВИМИ ЦІННОСТЯМИ ДЛЯ ЗБЕРЕЖЕННЯ (У СХІДНІЙ ЧАСТИНІ ЛІСІВ СУМСЬКОЇ ОБЛАСТІ)
}

\author{
Кременецька Євгенія Олексіївна \\ кандидат сільськогосподарських наук, доцент \\ Сумський національний аграрний університет, м. Суми, Україна \\ ORCID: 0000-0001-5581-7868 \\ e.kremenetska@gmail.com \\ Голуб Михайло Григорович \\ експерт товариства \\ НТ «Товариство лісової сертифрікації в Україні», м. Київ, Україна \\ mg.golub@ukr.net \\ Череповський Максим Володимирович \\ студент \\ Сумський національний аграрний університет, м. Суми, Україна \\ thenwewillflyfaraway@gmail.com
}

Лісова сертифрікація є однією із найбільш відомих у світі добровільних довкільних програм щодо сталого лісового менеджменту. Принципом 9 «Особливі цінності для збереження» добровільної лісової сертифрікації за схемою FSC® передбачається необхідність прийняття спеціальних заходів із ідентифрікації й збереження лісових територій із наявними особливими цінностями для збереження (ОЦЗ). Ідентифрікація ОЦЗ є дієвим інструментом лісової сертифрікації, який спонукає лісогосподарське підприємство враховувати інтереси широкого кола зацікавлених сторін та розробляти заходи щодо збереження біорізноманіття у лісах. Досліджувалися сучасні методичні підходи щодо ідентифрікації ОЦЗ на лісових територіях, а також їхнє практичне застосування у лісовому фонді державного підприємства "Сумське лісове господарство" (північно-східна частина України). Були використані матеріали лісовпорядкування, стандарти, посібники, звіти, доповіді, наукові публікації. Методи дослідження $€$ загальноприйнятими у лісовій сертифрікації за схемою FSC®. Застосовувався поділ ОЦЗ на категорії, які наведені у «FSC національному стандарті системи ведення лісового господарства для України» (2020). Розглянуто методичні підходи багатьох країн світу щодо підтримки лісових екосистем на територіях з ОЦЗ. Особлива увага надавалася висвітленню інформації, яка є пов'язаною із лісами, які зазнали мінімального турбування з боку людини (первинні ліси, квазіпралісові ділянки, старовікові ліси). Інтенсивне ведення лісового господарства призводить до втрати природних лісів та пов'язаного з ними біорізноманіття. Ці негативні тенденції стану біорізноманіття та фрункціонування лісових екосистем вимагають нових ініціатив. На рівні Європейського Союзу до нової ініціативи належить концепція зеленої інфрраструктури, спрямування якої полягає у забезпеченні біорізноманіття, стійкості середовища існування та екосистемних послуг. Ідентифбікація ОЦЗ 1 Видове різноманіття вимагає знань щодо природоохоронного статусу рослин та тварин, ОЦЗ 3 Екосистеми та оселища - застосування сучасних методик та володіння інформації щодо виділення: старовікових лісів, рослинних угруповань із «Зеленої книги України», національного каталогу біотопів України, IBA-територій тощо. Пошук ОЦЗ 5 Потреби громади та ОЦЗ 6 Культурні цінності потребує консультацій із зацікавленими сторонами. ОЦЗ 2 в Україні не виділяють. Важливим заходом є нанесення на карту контурів територій із ОЦЗ, символічне зображення їхніх категорій, позначення цінних та рідкісних біотопів тощо. Концепцію ОЦЗ можна вважати універсальною платфрормою, завдяки якій можна ідентисрікувати категорії тих лісових екосистем, які існують в умовах потенційної небезпеки. Значна частина таких лісів досіє незахищеними і потребують уваги суспільства.

Ключові слова: лісова сертифрікація, лісові екосистеми, біорізноманіття, особливі цінності для збереження (ОЦЗ), Сумська область, Україна.

DOI https://doi.org/10.32845/agrobio.2021.2.3

Вступ. Одним із пріоритетних напрямків у сфері екологічної безпеки держави $є$ охорона, використання і відтворення природних ресурсів. Реалізація концепції сталого розвитку $є$ можливою за умови імплементації міжнародних конвенцій та угод у національне законодавство із подальшим економіко-правовим регулюванням, у т. ч. й у сфері охорони та збереження біорізноманіття екосистем (Dubovich et al., 2019).

У лісовій політиці майже всіх країн, що надавали інформацію до звіту: «Ліс Європи, 2020: Стан лісів
Європи 2020» (FOREST EUROPE, 2020) є передбаченими цілі щодо підтримки, збереження та покращення біорізноманіття лісів. У кількісному виразі вказана політика має вираз у збільшенні площ охоронюваних лісів, обсягів мертвої деревини, а також у зупинці втрат видового різноманіття. Для досягнення своїх цілей 23 європейські країни застосовували інструменти правової (засоби - нові або змінені закони про ліси та супутні закони), фрінансової (державна фінансова підтримка фінансових втрат та збільшення витрат на спеціальне 
управління) та комунікаційної політики (збільшення витрат на комунікацію за допомогою різноманітних інформаційних каналів). Досягнення за останні п'ять років були зосереджені на збільшенні охоронюваних лісів та територій Natura 2000, пристосуванні до природних та інтегративних практик управління лісами та вдосконаленні моніторингу біорізноманіття.

Підтримки та відновлення потребують важливі властивості лісових екосистем, у такому випадку вони будуть здатними виконувати екологічну, соціальну та економічну ролі лісів (Chazdon, 2017).

Зацікавлені сторони із Камеруна наголошують на тому, що на теперішній час лісова сертифікація $є$ однією із найбільш відомих у світі добровільних довкільних програм щодо сталого лісового менеджменту (Nghobuoche et al., 2020).

Досягнення сталого управління лісами в Китаї набуває дедалі більшого значення 3 поінформованістю та усвідомленням значення лісів у охороні навколишнього середовища. Розробляється політика щодо мотивації власників до участі у програмах сертифікації лісів, у т. ч. компенсації у зв'язку із підвищенням ціни на деревину, а також інші стимулюючі механізми (Tian et al., 2021).

Концепцію «Особливих цінностей для збереження» (ОЦ3, англ. High Conservation Value, HCV) запропоновано Лісовою Опікунською Радою (англ. Forest Stewardship Council, FSC) у 1999 році, водночас збереження ОЦЗ стало однією із вимог для лісопромислових компаній, які прагнуть отримати сертифрікат за схемою FSC®. Головна ідея концепції ОЦЗ - ідентифікувати особливу цінність для збереження, яка потребує охорони та збалансованого використання.

До особливо цінних для збереження територій (ОЦЗТ; англ. High Conservation Value Areas, HCVAs) належать зони і фрізичні простори, які містять визначені особливі цінності для збереження (біологічні, екологічні, соціальні або культурні), та / або потрібні для існування та збереження таких цінностей (FSC nacional'nyj standart, 2020).

Лісові території із ОЦЗ потребують відповідного господарювання з метою підтримання або посилення виявлених ОЦ3 (Forest Stewardship Council A.C., 2000; Osoblyvo cinni, 2008). Таким чином, мета Концепції ОЦЗ полягає у розробці та впровадженні відповідного менеджменту таких лісових територій із виявленими ОЦЗ задля збереження і збільшення її високої екологічної та соціально-економічної цінності (Lesa vysokoj prirodoohrannoj cennosti, 2009).

Під час виявлення потенційних ОЦЗТ у Румунії до основних характеристик ОЦЗТ належали: різноманітна горизонтальна та вертикальна структура (змішаний склад порід у деревостані, різна висота дерев, наявність старовікових дерев, великі обсяги мертвої деревини); екологічна функціональність (контроль за ерозійними процесами, утримання поживних речовин); тривала часова безперервність; послуги екосистем (культурна цінність та спадщина, рекреаційна значущість) (PatruStupariu et al., 2013).

У результаті аналізу чинного національного законодавства щодо особливо цінних для збереження лісів (ОЦЗЛ) було встановлено, що концепція ОЦЗЛ є лише частково реалізованою у чинній нормативно-правовій базі ведення лісового господарства у вигляді категорій та підкатегорій захисності лісів. Відмічено, що ефективне використання концепції ОЦЗ гальмується внаслідок відсутності відповідних нормативних положень або через неузгодженість різних законів та інших законодавчих актів і підзаконних документів щодо визначень ОЦЗ та і господарювання у них (Morozjuk et al., 2015).

У звіті канадських дослідників щодо здійснення відповідальних рішень під час ведення лісового господарства доведено, що розвиток природоохоронних досягнень у Північній Америці є помітним після ідентифрікації лісових територій із наявними особливими цінностями для збереження (понад 60 \% утримувачів сертифікатів зробили це або знаходилися на стадії проходження) через FSC尺 аудити з лісоуправління за критерієм 6.4. та принципом 9). Проведене дослідження свідчить про те, що стратегія FSC призвела до збільшення ініціативи у регіонах щодо виявлення лісових територій із наявними особливими цінностями для збереження та розробки заходів щодо їхнього підтримання (Evaluating Conservation, 2007).

Втрата природних та старовікових лісів та пов'язаного 3 ними біорізноманіття продовжуються у всьому світі через значний антропогенний вплив (Curtis et al., 2018). Основним фактором зменшення показника первинної лісистості покриву в Європі є інтенсивне ведення лісового господарства, у тому числі й у Швеції, внаслідок довготривалого управління лісами з промисловою метою (Svensson et al., 2019), на даний час залишилася незначна частка цілісних (недоторканих) бореальних ландшафтів (Potapov et al., 2017; Svensson et al., 2020).

Площа цілісних лісових ландшафртів зменшується, отже, для збереження вони потребують певної стратегії щодо збереження. «Цілісними (недоторканими лісовими ландшафтами» вважаються лісові ділянки (не мають ознак / мають обмежені ознаки людської діяльності); вони характеризуються площею, яка є достатньо великою для збереження природного біорізноманіття (Svensson et al., 2020).

Ці негативні тенденції біорізноманіття та функціонування екосистем вимагають нових ініціатив, що забезпечують більш сприятливий статус збереження бореальних лісів у Швеції та в інших регіонах бореального регіону в майбутньому (Jonsson et al., 2019).

Такою новою ініціативою на рівні Європейського Союзу концепція зеленої інфраструктури, яка вже впроваджується або готується до впровадження в державах-членах (Chatzimentor et al., 2020), іï спрямування - забезпечення біорізноманіття, стійкості середовища існування та екосистемних послуг (Liquete et al., 2015).

Європейські природоохоронці знаходяться у постійному пошуці первинних лісів. Слід відмітити, що у Північній Європі інфрормація щодо первинних лісів є більш доступною, ніж у Східній Європі. У зв'язку з цим, до уваги приймається інформація не лише про пралісові ділянки, але й про лісові ділянки, які є: наближеними до пралісових; старовікові ліси, лісостани, які зростали довгий час без турбування з боку людини. На теперішній час багато ділянок не є виявленими та не є позначеними на мапах, внаслідок чого невідомим $€$ ступінь захисту, якого вони 
потребують. Дослідниками встановлено, що більшість із відомих первинних лісів зростають на природо-заповідних територіях (89 \%), але приблизно половина із них не мають сильного ступеню захисту. Незахищеними залишаються 11 \% первинних лісів. Виявлено загальну тенденцію щодо особливої небезпеки для існування ділянки тих первинних лісів, які $є$ невеликими за розмірами чи фррагментованими. Ідентифікація первинних лісів у Східній Європі є актуальним завданням сьогодення, оскільки ці ліси можуть потребувати певних зусиль щодо їхнього збереження. Саме тому ініціатива FSC (Принцип 9) щодо ідентифікації ОЦЗ є інструментом щодо ідентифікації лісів, які є наближеними до первиних із їхнім подальшим моніторингом та розробкою заходів щодо підтримання їхньої життєдіяльності (Sabatini et al., 2019).

Ідентифікація та розробка режимів збереження для лісових територій із виявленими ОЦЗ належать до основних вимог Принципів і критеріїв відповідального управління лісами.

Принцип 9 «Особливі цінності для збереження» має на меті ідентифрікацію ОЦЗ, місць їхнього розташування та стану, розробку стратегій щодо їх підтримки та збереження, впровадження їх у систему ведення господарства, а також впровадження системи моніторингу їх стану (FSC nacional'nyj standart, 2020)

У табл. 1 наводяться ознаки для ідентифікації різних категорій ОЦЗ відповідно до FSC-STD-UKR-01-2019 V 1-0 (FSC nacional'nyj standart, 2020).

Відповідно до табл. 1 відповідно до FSC-STDUKR-01-2019 V 1-0 (FSC nacional'nyj standart, 2020) вказується 6 категорій ОЦ3: ОЦ3 1, ОЦ3 2, ОЦ3 3, ОЦ3 4, ОЦ3 5, ОЦ3 6. Категорія ОЦ3 2 в Україні не виділяється. Для категорії ОЦЗ 1 та ОЦЗ 4 розрізняють підкатегорії.

Мета досліджень полягала в огляді сучасних методичних підходів щодо ідентифрікації особливих цінностей для збереження, а також у застосуванні вимог «Національного стандарту системи ведення лісового господарства для України» (2020) щодо встановлення категорій ОЦЗ у лісовому фонді ДП «Сумське лісове господар- ство» (FSC nacional'nyj standart, 2020). Об'єктом дослідження є особливі цінності для збереження (ОЦЗ) на лісових територіях. Предметом дослідження $€$ сучасні методичні підходи щодо ідентифікації ОЦЗ на лісових територіях, а також їхнє практичне застосування у лісовому фонді ДП “Сумське лісове господарство”.

Матеріали і методи досліджень. Матеріали дослідження - матеріали, за допомогою яких можна виявити особливі цінності для збереження (ОЦЗ) на лісових територіях ДП «Сумське лісове господарство».

Методи дослідження - загальноприйняті у лісовій сертифікації за схемою FSC尺, яка наведена у практичних посібниках та рекомендаціях: у практичному посібнику WWF для України (Osoblyvo cinni, 2008); рекомендаціях з лісової сертифрікації лісогосподарських підприємств (Bondaruk \& Buksha, 2010); у практичному посібнику 3 ідентифікації лісів високої природоохранної цінності (Dzhennyngs et al., 2005); у практичному посібнику для визначення та управління лісами, які включають важливі осередки видового різноманіття у Мармароському транскордонному регіоні (Румунія-Україна) (Proc' et al., 2014), у посібнику для визначення ОЦЗЛ у вищевказаному регіоні Мармарощини (Румунія-Україна) та господарювання в них (Vlad et al., 2014); методичних рекомендаціях з виділення, моніторингу та охорони ОЦЗЛ (Karpuk et al., 2015).

Ідентифікація категорії ОЦЗ 1 Видове різноманіття здійснювалася з поділом на підкатегорії: ОЦ3 1.1 Природно-заповідні території; ОЦЗ 1.2 Види, що перебувають під загрозою знищення, вимирають та ендемічні види; ОЦЗ 1.3 Ключові сезонні місця концентрації тварин.

Пошук ОЦЗ 1.1 Природно-заповідні території проводився із врахуванням лісових територій, які належать до природно-заповідного фронду України (ПЗФ), міжнародних конвенцій і угод, підписаних Україною. Користувалися переліком територій та об'єктів, які містяться у «Державному кадастрі територій и об'єктів природно-заповідного фонду України» (Derzhavnyj kadastr, 2019), ознайомлювалися із охоронними зобов'язаннями на об'єкти ПЗФ, планом організації та ведення

Таблиця 1

Ознаки для ідентифікації ОЦЗ відповідно до Принципу 9 (FSC nacional'nyj standart, 2020)

\begin{tabular}{|c|c|}
\hline Категорія та назва ОЦЗ & Ознаки для ідентифікації ОЦЗ \\
\hline ОЦ3 1: Видове різноманіття. & $\begin{array}{l}\text { Концентрації біологічного різноманіття, включно з ендемічними, рідкісними видами } \\
\text { і видами, що перебувають під загрозою, або зникають, які є істотними на світовому, } \\
\text { регіональному або національному рівнях. }\end{array}$ \\
\hline $\begin{array}{l}\text { ОЦЗ 2: Екосистеми та їхні } \\
\text { мозаїки ландшафртного рівня. }\end{array}$ & $\begin{array}{l}\text { Цілісні лісові ландшафти, великі екосистеми ландшафтного рівня та мозаїки екосистем, } \\
\text { які є істотними на світовому, регіональному або національному рівнях та містять } \\
\text { життєздатні популяції переважної більшості природно притаманних їм видів, } \\
\text { з природними структурами їх розповсюдження та рясності. }\end{array}$ \\
\hline Оц3 3: Екосистеми та оселища. & $\begin{array}{l}\text { Рідкісні й такі, що перебувають під загрозою або зникають екосистеми, } \\
\text { оселища або рефугіуми. }\end{array}$ \\
\hline $\begin{array}{l}\text { ОЦ3 4: Критичні послуги } \\
\text { екосистем. }\end{array}$ & $\begin{array}{l}\text { Основні послуги екосистем у критичних ситуаціях, } \\
\text { включно із захистом водозборів і запобіганням ерозії вразливих ґрунтів і схилів. }\end{array}$ \\
\hline ОЦ3 5: Потреби громади. & $\begin{array}{l}\text { Ділянки та ресурси, визначальні для задоволення основних потреб місцевих громад } \\
\text { або тубільних народів (наприклад, у засобах для існування, лікування, харчування, } \\
\text { забезпечення водою), визначені шляхом залучення цих громад або тубільних народів. }\end{array}$ \\
\hline ОЦЗ 6: Культурні цінності. & $\begin{array}{l}\text { Ділянки, ресурси, оселища та ландшафти світового або національного культурного, } \\
\text { археологічного або історичного значення та/або критичної культурної, екологічної, } \\
\text { економічної чи релігійної/священної важливості для традиційних культур місцевих громад } \\
\text { або тубільних народів, визначені шляхом залучення цих місцевих громад або тубільних } \\
\text { народів (Джерело: базується на FSC-STD-01-001 V5-0). }\end{array}$ \\
\hline
\end{tabular}


лісового господарства (Пояснювальна записка) (Proekt organizacii...Sums'kogo oblasnogo upravlinnja lisovogo ta myslyvs'kogo gospodarstva Derzhavnogo agentstva lisovyh resursiv Ukrai'ny, 2018), таксаційними описами лісових насаджень (Proekt organizacii' ta rozvytku... Mogryc'ke lisnyctvo, 2018; Proekt organizacii' ta rozvytku... Nyzivs'ke lisnyctvo, 2018; Proekt organizacii' ta rozvytku... Pishchans'kelisnyctvo,2018; Proektorganizacii'tarozvytku... Sums'ke lisnyctvo, 2018), планами лісонасаджень (Plan lisonasadzhen' DP «Sums'kyj lisgosp» Mogryc'ke lisnyctvo Sums'ka oblast', 2017; Plan lisonasadzhen' DP «Sums'kyj lisgosp» Pishhans'ke lisnyctvo Sums'ka oblast', 2017; Plan lisonasadzhen DP «Sumy lisgosp» Nizivske lisnitstvo Sumy region, 2017; Plan lisonasadzhen' DP «Sums'kyj lisgosp» Sums'ke lisnyctvo Sums'ka oblast', 2017).

Виділення ОЦЗ 1.2 Види, що перебувають під загрозою знищення, вимирають та ендемічні види проводилося на лісових ділянках із наявними рідкісними, ендемічними, зникаючими видами рослин та тварин. Ліси із популяціями таких видів характеризуються вразливістю біотопів. Лісові території із наявністю такого виду (групи видів) утворюють життєздатні популяції / спостерігаються регулярно (Osoblyvo cinni, 2008).

Під час ідентифікації ОЦЗ 1.2 нами здійснювався аналіз інформації, яка міститься у: виданнях Червоної книги України (Chervona knyga Ukrai'ny. Roslynnyj svit, 2009; Chervona knyga Ukrai'ny. Tvarynnyj svit; 2009), міжнародних конвенціях та угодах, які ратифріковані в Україні (Bondaruk et al. 2013; Konvencija pro ohoronu biologichnogo riznomanittja, 1992; Konvencija pro ohoronu dykoi' flory ta fauny ta pryrodnyh seredovyshh i'h isnuvannja v Jevropi, 1979; Konvencija pro vodno-bolotni ugiddja, shho majut' mizhnarodne znachennja, golovnym chynom jak seredovyshha isnuvannja vodoplavnyh ptahiv, 1971; Konvencija pro zberezhennja migrujuchyh vydiv dykyh tvaryn, 1979; Ugoda pro zberezhennja kazhaniv v Jevropi, 1995), у офріційних переліках регіонально рідкісних рослин адміністративних територій України (Andrijenko \& Peregrym, 2012). Вивчалися також публікації у наукових збірниках та інтернет-джерелах (Dopovid' pro stan..., 2018; Gorban' et al., 2009; Interaktyvni karty..., 2020).

Ідентифікація ОЦЗ 1.3 здійснювалася на лісових територіях 3 критичними тимчасовими концентраціями видів (це можуть бути місця розмноження, маршрути міграції, коридори переміщення видів тощо), відповідно до знань про міграцію тварин, певні фази їхнього розвитку та фази репродукції. Протягом дії цих фаз тварини $€$ найбільш вразливими. Осередки концентрації тварин мають циклічність, яка пов'язана з сезонними циклами чи 3 життєвими циклами тварин. Приймався до уваги перелік раритетних видів, який наведено у практичному посібнику «Особливо цінні для збереження ліси: визначення та господарювання» (Osoblyvo cinni, 2008).

ОЦЗ 2 Екосистеми та їхні мозаїки ландшафртного рівня в Україні не ідентифрікують.

Ідентифікація ОЦЗ 3 Екосистеми та оселища проводилася з метою пошуку оселищ, екосистем, рефугій. Вона відбувається за наявності біотопів: зникаючих, рідкісних, вразливих; комплексів цих лісових біотопів із іншими типами біотопів; природних лісових біотопів із старовіковими деревостанами. Під час ідентифікації ОЦЗ 3 приймалися до уваги: характерні риси рослинних угрупувань «Зеленої Книги України» (Sums'ke oblasne upravlinnja; Zelena knyga Ukrai'ny, 2009); інформація про наявність зникаючих, рідкісних та вразливих біотопів (Nacional'nyj catalog..., 2018; Plan lisonasadzhen'... Mogryc'ke lisnyctvo, 2017; Plan lisonasadzhen'... Pishhans'ke lisnyctvo, 2017; Plan lisonasadzhen'... Nizivske lisnitstvo, 2017; Plan lisonasadzhen'... Sums'ke lisnyctvo, 2017; Proekt organizacii'..."Sums'ke lisove gospodarstvo", 2018; Proekt organizacii' ta rozvytku...Mogryc'ke lisnyctvo, 2018; Proekt organizacii' ta rozvytku...Nyzivs'ke lisnyctvo, 2018; Proekt organizacii' ta rozvytku...Pishchans'ke lisnyctvo, 2018; Proekt organizacii' ta rozvytku...Sums'ke lisnyctvo, 2018; Sums'ke oblasne upravlinnja; Zelena knyga Ukrai'ny, 2009); про ідентифікацію старовікових лісів, квазіпралісів і пралісів у посібниках, наукових публікаціях, звітах, інтерактивних картах (Aleksijuk, 2019; Proekt organizacii'... "Sums'ke lisove gospodarstvo", 2018; Proekt organizacii' ta rozvytku...Mogryc'ke lisnyctvo, 2018; Proekt organizacii' ta rozvytku...Nyzivs'ke lisnyctvo, 2018; Proekt organizacii' ta rozvytku...Pishchans'ke lisnyctvo, 2018; Proekt organizacii' ta rozvytku...Sums'ke lisnyctvo, 2018; Shparyk et al., 2015; Sums'ke oblasne upravlinnja; Veb-karta starovikovyh); про генетичні резервати тих деревних порід, які $€$ аборигенними лісовими деревними видами (Proekt organizacii'... "Sums'ke lisove gospodarstvo", 2018; Proekt organizacii' ta rozvytku...Mogryc'ke lisnyctvo, 2018; Proekt organizacii' ta rozvytku...Nyzivs'ke lisnyctvo, 2018; Proekt organizacii' ta rozvytku...Pishchans'ke lisnyctvo, 2018; Proekt organizacii' ta rozvytku...Sums'ke lisnyctvo, 2018; Sums'ke oblasne upravlinnja); інтерактивні карти Смарагдової мережі України (Interaktyvni karty Smaragdovoi' merezhi Ukrai'ny); важливі орнітологічні території (Mykytjuk, 1999); Рамсарські водно-болотні території, які повністю або частково вкриті лісовою рослинністю, які перелічені в додатку 5 стандарту FSC-NRA-UA V1-1 «FSC оцінка ризику контрольованої деревини для України» (Standart FSC-NRA-UA V1-1FSC); «Доповідь про стан навколишнього природного середовища в Сумській області» (Dopovid' pro stan, 2018); «Висновки про результати проведення польових досліджень та завершального етапу визначення належності лісових територій до пралісів, квазіпралісів і природних лісів» (Aleksijuk, 2019).

Ідентифікація ОЦЗ 4. Критичні послуги екосистем проводилася з метою пошуку тих лісів, для яких виконання захисних фрункцій (водоохоронні, ґрунтозахисні та інші) $є$ визначальним, тобто мають особливу цінність.

Лісами із потенційною наявністю ОЦ3 4 вважають ліси, які є ключовими для захисту: водозборів і водних об'єктів; джерел питної води; від ерозії (протиерозійні ліси); сільськогосподарських угідь; інженерних комунікацій, а також ліси, які слугують бар'єрами для поширення пожеж,ліси навколо карстових утворень та інших типів природних підземних порожнин.

Лісовими територіями із ОЦЗ 4 вважають особливо захисні лісові ділянки відповідно до статті 41 «Лісового кодексу України» (Lisovyj kodeks Ukrai'ny) та до «Порядку 
поділу лісів на категорії та виділення особливо захисних лісових ділянок» (Porjadok podilu lisiv), які визначаються під час лісовпорядкування (Proekt organizacii'... "Sums'ke lisove gospodarstvo", 2018; Proekt organizacii' ta rozvytku....Mogryc'ke lisnyctvo, 2018; Proekt organizacii' ta rozvytku...Nyzivs'ke lisnyctvo, 2018; Proekt organizacii' ta rozvytku...Pishchans'ke lisnyctvo, 2018; Proekt organizacii' ta rozvytku...Sums'ke lisnyctvo, 2018).

Категорія ОЦ3 5. Потреби громади має особливу для збереження цінність із соціальним значенням (будівельні матеріали, питна вода, їжа, сировина для ремесел, паливо тощо), в т. ч. враховується дохід, який місцеві громади отримують від збору та продажу лісових ресурсівта продуктів із них. Таку інформацію можна отримати із матеріалів лісовпорядкування, шляхом соціального опитування місцевого населення та спеціалістів підприємства.

3 метою ідентифікації ОЦ3 6. Культурні цінності здійснювався пошук таких лісів: ліси, які пов'язані з релігійними цінностями та традиціями; ліси, на території яких розташовані об'єкти історичного минулого; ліси, які мають естетичну чи дозвільно-рекреаційну цінність; ліси із культурною чи культурно-побутовою цінністю для життєдіяльності громади; ліси, які пов'язані з фольклорною спадщиною. Дані про лісові території розшукувалися також уреєстрах: реєстрі пам яток культурної спадщини України національного значення» (Rejestr pam jatok kul'turnoi' spadshhyny Ukrai'ny nacional'nogo) та у реєстрі пам'яток культурної спадщини України місцевого значення» (Rejestr pam jatok kul'turnoi' spadshhyny Ukrai'ny miscevogo znachennja), але не були знайдені у вищенаведених джерелах. Частина даних була отримана під час перегляду матеріалів лісовпорядкування (Proekt organizacii'... "Sums'ke lisove gospodarstvo", 2018; Proekt organizacii' ta rozvytku...Mogryc'ke lisnyctvo, 2018; Proekt organizacii' ta rozvytku...Nyzivs'ke lisnyctvo, 2018; Proekt organizacii' ta rozvytku...Pishchans'ke lisnyctvo, 2018; Proekt organizacii' ta rozvytku...Sums'ke lisnyctvo, 2018), частина - під час спілкування із зацікавленими сторонами.

Результати. За даними лісовпорядкування [50] площа ДП «Сумське ЛГ» становить 26687,4 га. У підприємстві функціонує 4 лісництва: Сумське (7534,6 га), Піщанське (8049,5 га), Могрицьке (6838,3 га), Низівське (4265,0 га).

У лісовому фонді ДП «Сумське лісове господарство» немає категорії «експлуатаційні ліси» (відповідно до поділу лісів за екологічним та соціально-економічним значенням у Лісовому кодексі України (Lisovyj kodeks Ukrai'ny), призначення яких полягає у задоволенні потреб національної економіки у деревині. Усі ліси належать до лісів із обмеженим режимом лісокористування та виконують переважно рекреаційну, природоохоронну та захисну функції. Переважає категорія «рекреаційно-оздоровчі ліси» (21109,4 га; 79,1%), в т. ч. ліси в межах населених пунктів (836,1 га), лісопаркова частина лісів зелених зон (3458,9 га), лісогосподарська частина лісів зелених зон (16814,4 га). Значну частину займає категорія «ліси природоохоронного, наукового, історико-культурного призначення» (4058,0 га; 15,2%) та «захисні ліси» (1520,0 га; 5,7 \%). До категорії «ліси природоохоронного, наукового, історико-культурного призначення» належить пам'ятка природи (1,0 га) та заказники (4057,0 га). До категорії «захисні ліси» віднесено ліси уздовж берегів річок, навколо озер, водоймищ та ін. (90,0 га), інші захисні ліси (1237,5 га), байрачні ліси (192,5 га).

За лісорослинним районуванням України територія ДП «Сумське ЛГ» відноситься до зони Лівобережно-Дніпровського Лісостепу, за лісотипологічним - до лісотипологічного району Дніпровських свіжих кленово-липових дібров (Vorob'ev, 1953).

Кількість опадів є достатньою для зростання основних лісоутворюючих порід (дуб звичайний, ясен звичайний, клен гостролистий, липа дрібнолиста). Клімат території помірно-континентальний. Серед фракторів, які лімітують ріст і розвиток насаджень, можна вказати на пізні весняні та ранні осінні заморозки, сильні сухі вітри.

Рельєф території ДП «Сумське ЛГ» - рівнинний. У східній частині наявними $€$ долини малих річок, струмки, яри, балки (коливанням висот - 115-230 м н. р. м.), у західній частині - лісові насадження зростають на незначній площі ярів і балок, в той час як рівні площі використовуються задля вирощування сільськогосподарських культур.

Основні типи і види ґрунтів: сірі лісові (темно-сірі, сірі і світло-сірі), дерново-підзолисті, дерново-підзолисті глеєві, болотні (торф'яно-глеєві і торф'яні). Основні типи лісу: В ДС - 3,8\%; С ЛДС - $17 \%$; С ЛДС - 3,6 \%; Д $_{2}$ КлД - 65,2 \%. За ступенем вологості більша частина ґрунтів відноситься до свіжих.

До ОЦЗ 1.1 Природно-заповідні території належать такі об'єкти природно-заповідного фонду на території ДП «Сумське ЛГ» Derzhavnyj kadastr..., 2009; Proekt organizacii'..."Sums'ke lisove gospodarstvo", 2018): ботанічний заказник загальнодержавного значення «Банний яр» (Могрицьке лісництво, кв. 26, 42-43, 52, площею 236,0 га); орнітологічний заказник загальнодержавного значення «Журавлиний» (Низівське лісництво, кв. 41, 48, 57, 62, 69, площею 258 га); ландшафтний заказник місцевого значення «Битицький» (Сумське лісництво, кв. 127-135, 137; Могрицьке лісництво, кВ. 115-116, площею 867,5 га); загальнозоологічний заказник місцевого значення «Бобровий» (Сумське лісництво, кв. 85, 93, 95, площею 163,0 га); ботанічний заказник місцевого значення «Лунарієвий» (Могрицьке лісництво, кв. 40-41, 51, 53-55, площею 340,0 га); гідрологічний заказник місцевого значення "Ворожбянський» (Низівське лісництво кв. 15, 16, 17, 20, 21, 22, 25, 26, 31, 38, 45, 52, 58, 63, площею 764,0 га); пам'ятка природи місцевого значення «Джерело Барвінкове-1» (Низівське лісництво кв. 79 вид. 8 ур. "Мамаєвщина”, площею 0,02 га); пам'ятка природи місцевого значення «Джерело Барвінкове-2» Низівське лісництво кв. 79 вид.12 ур. "Мамаєвщина”, площею 0,02 га; гідрологічна пам'ятка природи місцевого значення «Джерело Вакалівське» Піщанське лісництво, кв. 123, діл. 17, 25, площею 1 га.

Під час ідентиффікації ОЦЗ 1.2 Види, що перебувають під загрозою знищення, вимирають та ендемічні види нами було з'ясовано, які види рослин та тварин Сумської області мають вказаний природоохоронний статус. 
До видів рослин, які включено до «Червоної книги України» (Chervona knyga Ukrai'ny. Roslynnyj, 2009) належать: гніздівка звичайна (Neottia nidus-avis L.), любка дволиста (Platanthera bifolia L.), лілія лісова (Lilium martagon L.), пальчатокорінник Фукса (Dactylorhiza fuchsia Druce), пальчатокорінник м'ясочервоний (Dactylorhiza incarnata L.), коручка чемерниковидна (Epipactis helleborine L.), лунарія оживаюча (Lunaria rediviva L.), цибуля ведмежа (Allium ursinum L.), зозулині сльози яйцевидні (Listera ovata L.), мутин собачий (Mutinus caninus Huds.).

До видів рослин, що підлягають особливій охороні, належать: волошка сумська (Centaurea sumensis Kalen.), осока ячменевидна (Carex hordeistichos Vill.), страусове перо звичайне (Matteuccia struthiopteris L.), росичка круглолиста (Drosera rotundifolia L.), сон широколистий (Pulsatilla patens L.), наперстянка великоцвіта (Digitalis grandiflora Mill.), воронець колосистий (Actaea spicata L.), зірочник гайовий (Stellaria nemorum L.), купальниця європейська (Trollius europaeus L.).

До Червоного списку рослин Сумської області (Andrijenko \& Peregrym, 2012) належать: зірочник гайовий (Stellaria nemorum L.), зубниця п'ятилиста (Dentaria quinquefolia M.Bieb.), костриця найвища (Festuca altissima All.), ряст Маршала (Corydalis marschalliana Pers.).

До видів тварин, які включено до «Червоної книги України» (Chervona knyga Ukrai'ny. Tvarynnyj, 2009) належать: видра річкова (Lutra lutra Linnaeus), мінога українська (Eudontomyzon mariae Berg), кутора мала (Neomys anomalus Cabrera), мідянка звичайна (Coronella austriaca Laurenti), горностай (Mustela erminea Linnaeus), журавель сірий (Grus grus Linnaeus), шуліка чорний (Milvus migrans Boddaert), балабан (Falco cherrug Gray), лунь лучний (Circus pygargus Linnaeus), сорокопуд сірий (Lanius excubitor Linnaeus), жук-олень (Lucanus cervus cervus Linnaeus), дозорець імператора (Anax imperator Leach), красотіл пахучий (Calosoma (s.str.) sycophanta Linnaeus), п'явка медична (Hirudo medicinalis Linnaeus), стрічкарка тополева (Limenitis populi Linnaeus), стрічкарка блакитна (Catocala fraxini Linnaeus), джміль моховий (Bombus muscorum Linnaeus).

До видів тварин, що підлягають особливій охороні, належать: борсук (Meles meles Linnaeus), черепаха болотяна (Emys orbicularis Linnaeus), ремез (Remiz pendulinus Linnaeus), сова сіра (Strix aluco Linnaeus), деркач (Crex crex Linnaeus), бугай (Botaurus stellaris Linnaeus).

Наведемо обґрунтування віднесення частини із вище перерахованих об'єктів ПЗФ до ОЦЗ 1.2. У ботанічному заказнику загальнодержавного значення «Банний яр» являє собою масив широколистяного лісу, зростають реліктові види рослин: костриця найвища (Festuca altissima All.), страусове перо (Matteuccia struthiopteris L.), а також червонокнижні вид рослин - лунарія оживаюча (Lunaria rediviva L.) і цибуля ведмежа (Allium ursinum L.).

B орнітологічному заказнику загальнодержавного значення «Журавлиний» у віковому дубово-сосновому лісовому масиві трапляються червонокнижні рослини: любка дволиста (Platanthera bifolia L.), пальчатокорінник травневий (Dactylorhiza majalis Rchb.), косарики болотні (Gladiolus palustris Gaudin), а також представники червонокнижної фауни: жук-олень (Lucanus cervus Linnaeus), махаон (Papilio machaon Linnaeus), джміль моховий (Bombus muscorumFabricius), соня садова (Eliomys quercinus Linnaeus), лелека чорний (Ciconia nigra Linnaeus), лунь польовий (Circus cyaneus Linnaeus), сорокопуд сірий (Lanius excubitor Linnaeus).

У ландшафртному заказнику місцевого значення «Битицький» у липово-кленово-дубових лісових масивах природного походження зростають червонокнижні рослини: пальчатокорінник м'ясочервоний (Dactylorhiza incarnate L.), коручка чемерникоподібна (Epipactis helleborine L.), грифола зонтична (Grifola umbellata Pers.). Тут мешкають червонокнижні тварини: лелека чорний (Ciconia nigra Linnaeus), орел-карлик (Aquila pennata Gmelin), мідянка (Coronella austriaca Laurenti), видра річкова (Lutralutra Linnaeus), горностай (Mustela ermine Linnaeus), вечірниця мала (Nyctalus leisleri Kuhl), бражник мертва голова (Acherontia atropos Linnaeus), райдужниця велика (Apatura iris Linnaeus), мнемозина (Parnassius mnemosyne Linnaeus), махаон (Papilio machaon Linnaeus), поліксена (Zerynthia polyxena Denis \& Schiffermuller).

У ботанічному заказнику місцевого значення «Лунарієвий» у лісостані природного походженням із переважанням липи дрібнолистої, клена гостролистого та дуба звичайного охороняються місця зростання лунарії оживаючої (Lunaria rediviva L.), цибулі ведмежої (Allium ursinum L.), які включені до «Червоної книги України».

ОЦЗ 1.3 Ключові сезонні місия концентрації тварин охороняються у орнітологічному заказнику загальнодержавного значення «Журавлинний» - постійні місця гніздування рідкісного червонокнижного птаха - сірого журавля (Grus grus Linnaeus) та у загальнозоологічному заказнику місцевого значення «Бобровий» (частина ділянок заплав річок Сейму та Виру) - місце концентрації бобрів (Castor Linnaeus), кабанів (Sus scrofa Linnaeus), козуль (Capreolus capreolus Gray), єнотоподібного собаки (Nyctereutes procyonoides Gray). Ідентифрікація ОЦ3 1.3 потребує подальших польових досліджень. Можна було б застосувати підхід багатьох лісогосподарських підприємств щодо включення до ОЦЗ 1.3 тих ділянок, які виділені як відтворювальні ділянки для мисливських тварин.

ОЦ3 3. Екосистеми та оселища ідентифікувалися нами під час ознайомлення із матеріалами «Зеленої книги України»:

1. Угруповання «Формації латаття білого (Nymphaea alba L.) та глечиків жовтих (Nuphar lutea L.)» охороняються у ландшафтному заказнику місцевого значення «Битицький» відповідно до видання «Зелена книга України» (Zelena knyga Ukrai'ny, 2009).

2. IBA територія № 63 - у лісовому фонді Піщанського та Могрицького лісництв площею 11600 га відповідно до додатку 4 «Перелік IBA-територій важливі для птахів території (Important Bird Areas - IBAs), повністю або частково вкриті лісовою рослинністю в Україні» (Standart FSC-NRA-UA V1-1FSC).

3. Старовікові ліси ідентифіковано за «Веб-картою старовікових лісів Українського Полісся» (Ukrai'ns'ka pryrodoohoronna grupa; Veb-karta starovikovyh lisiv). 
Лісівничо-таксаційна характеристика старовікових насаджень «Сумське лісове господарство» (у розрізі таксаційних виділів) наведена у табл. 2.

Відповідно до табл. 2 у Сумському лісництві виділено 1 таксаційний виділ, у Могрицькому - 9, у Піщанському 3, у Низівському - 5. Кожен із виділів належить до особливо захисних лісових ділянок (ОЗЛД) різних категорій: лісові ділянки на особливо охоронних частинах заказників, лісові ділянки в ярах, балках і річкових долинах, берегозахисні лісові ділянки. У складі переважає дуб звичайний. Вік - від 121 до 190 років.

Старовікові ліси у Могрицькому лісництві ідентифріковані (Ukrai'ns'ka pryrodoohoronna grupa; Veb-karta starovikovyh lisiv) у таксаційних кварталах 5, 9, 10, 14, 15. В усіх таксаційних кварталах, крім кварталу 5, на схилах північної та південної експозиції із стрімкістю від 10 до 30 зростають деревостани віком 160-170 років. Лісоутворюючими деревними породами є дуб звичайний та ясен звичайний із супутніми породами - липою дрібнолистою та кленом гостролистим. Деревостани мають вегетативне походження, окрім насадження у Могрицькому лісництві, кв.15, вид. 6.Типи лісу - $D_{2}$ КЛД або $D_{3}$ KЛД. Таксаційні квартали належать до категорії лісу - лісогосподарська частина лісів зелених зон.

Праліси та квазіпраліси, обєкти Смарагдової мережі, а також Рамсарські водно-болотні території, у ДП «Сумське ЛГ» не виявлено (Aleksijuk, 2019; Interaktyvni karty
Smaragdovoi'; Mykytjuk, 1999; Standart FSC-NRA-UA V1-1FSC).

До ОЦЗ 4 належить гідрологічний заказник місцевого значення «Ворожбянський» - лісовий масив, який розташований в заплаві річки Псел та відіграє велику роль у стабілізації рівня грунтових вод.

До ОЦЗ 4.1. Ліси, які мають особливо водоохоронне значення належать берегозахисні лісові ділянки загальною площею 605,7 га, у т. ч. (у розрізі лісництв): Могрицьке - 97,3 га, Низівське - 81,8 га, Піщанське 194,5 га, Сумське - 232,1 га.

До ОЦЗ 4.2. Ліси, які мають особливо протиерозійне значення віднесено лісові ділянкив ярах, балках і річкових долинах площею 2047 га (у розрізі лісництв): Могрицьке - 1135,3 га, Низівське - 122,1 га, Піщанське 305 га, Сумське - 118,3 га. До лісових ділянок на схилах ярів, балок, обривів, осипів і зсувів віднесено (у розрізі лісництв): Низівське - 7,4 га, Піщанське - 155,8 га, Сумське - 3,1 га.

До ОЦЗ 4.3. Лісові території, що мають особливе протипожежне значення належить 89,6 га. До лісових ділянок, що прилягають до залізниць, автодоріг віднесено (у розрізі лісництв): Низівське - 1,5 га, Піщанське 40,2 га, Сумське - 47,9 га.

До ОЦЗ 5. Потреби громади віднесено 5056,8 га. До лісових ділянок із насадженнями-медоносами (липові) віднесено 760,4 га (у розрізі лісництв): Могрицьке -

Таблиця 2

Лісівничо-таксаційна характеристика старовікових насаджень у ДП «Сумське лісове господарство»

\begin{tabular}{|c|c|c|c|c|c|c|c|c|c|c|}
\hline $\begin{array}{l}\text { № } \\
\text { ח/ח }\end{array}$ & Кв. & вид. & $\begin{array}{c}\text { Площа, } \\
\text { га }\end{array}$ & Склад & $\begin{array}{l}\text { Кате- } \\
\text { горія } \\
\text { ОЗЛД* }\end{array}$ & $\begin{array}{c}\text { Вік, } \\
\text { р. }\end{array}$ & $\begin{array}{c}\text { Боні- } \\
\text { тет }\end{array}$ & Тип лісу & Повнота & $\mathbf{M}^{3} / \mathbf{r a}$ \\
\hline \multicolumn{11}{|c|}{ Сумське лісництво } \\
\hline 1 & 135 & 25 & 6,8 & 4ДЗ3ЯЗ2ЛПД1КЛГ+БРС & 0043 & 165 & 2 & $\mathrm{D}_{3}$ КЛД & 0,6 & 320 \\
\hline \multicolumn{11}{|c|}{ Могрицьке лісництво } \\
\hline 2 & 9 & 20 & 2,8 & 5ДЗ4ЯЗ1КЛГ+ЛПД+БРС+ОС & ЯБРД & 170 & 1 & $\mathrm{D}_{2}$ КЛД & 0,6 & 400 \\
\hline 3 & 9 & 21 & 9,3 & 4ДЗ4ЯЗ1ЛПД1КЛГ+КЛП+БРС+ОС & ЯБРД & 170 & 1 & $\mathrm{D}_{2} \mathrm{KЛД}$ & 0,7 & 430 \\
\hline 4 & 10 & 4 & 15,0 & 7ДЗ1яЗ1ЛПД1КЛг & ЯБРД & 160 & 1 & $\mathrm{D}_{2} \mathrm{KЛД}$ & 0,7 & 440 \\
\hline 5 & 10 & 6 & 4,9 & 6ДЗ2КЛГ1ЯЗ1ЛПД+БРС & ЯБРД & 160 & 1 & $\mathrm{D}_{2} \mathrm{KЛД}$ & 0,6 & 350 \\
\hline 6 & 14 & 5 & 3,0 & 4ДЗ3ЯЗ2ЛПД1КЛГ+БРС+ОС & & 160 & 2 & $\mathrm{D}_{2} \mathrm{KЛД}$ & 0,8 & 430 \\
\hline 7 & 14 & 10 & 1,0 & 7ДЗ2ЯЗ1КЛГ+ЛПД+ОС & ЯБРД & 160 & 1 & $\mathrm{D}_{2} \mathrm{KЛД}$ & 0,7 & 510 \\
\hline 8 & 14 & 12 & 2,8 & 4ДЗ3ЯЗ2КЛГ1ЛПД+БРС+ОС & ЯБРД & 160 & 1 & $\mathrm{D}_{2} \mathrm{KЛДД}$ & 0,7 & 440 \\
\hline 9 & 15 & 1 & 4,1 & 5ДЗ4ЯЗ1КЛГ+ЛПД+БРС+ОС & ЯБРД & 170 & 2 & $\mathrm{D}_{2} \mathrm{КЛД}$ & 0,6 & 350 \\
\hline 10 & 15 & 6 & 5,1 & 7ДЗ2ЯЗ1КЛГ+ЛПД+ОС & ЯБРД & 121 & 2 & $\mathrm{D}_{2}$ КЛД & 0,6 & 320 \\
\hline \multicolumn{11}{|c|}{ Піщанське лісництво } \\
\hline 11 & 135 & 3 & 4,6 & 4ДЗ3ЛПД2КЛГ1ЯЗ+БРС & ЯБРД & 160 & 1 & $\mathrm{D}_{2}$ КЛД & 0,5 & 300 \\
\hline 12 & 145 & 3 & 4,7 & ЗДЗ3ЛПДЗКЛГ1ЯЗ+БРС+БП+ОС & ЯБРД & 145 & 1 & $\mathrm{D}_{2}$ КЛД & 0,5 & 260 \\
\hline 13 & 145 & 5 & 3,3 & 4КЛГЗЯЗ2ЛПД1ДЗ+БРС & ЯБРД & 145 & 2 & $\mathrm{D}_{2} \mathrm{KЛД}$ & 0,6 & 300 \\
\hline \multicolumn{11}{|c|}{ Низівське лісництво } \\
\hline 14 & 18 & 8 & 0,6 & 9ДЗ1ЛПД & БЗЛД* & 190 & 2 & $\mathrm{D}_{2} \mathrm{KЛД}$ & 0,3 & 140 \\
\hline 15 & 31 & 9 & 1,4 & 6ДЗЗЯЗ1КЛГ+ОС+ЛПД+БП & 0043 & 150 & 1 & $\mathrm{C}_{2}$ ЛДС & 0,7 & 390 \\
\hline 16 & 38 & 1 & 1,9 & 7ДЗЗЯЗ+БРС+ОС & 0043 & 170 & 2 & $\mathrm{C}_{2}$ ЛДС & 0,5 & 250 \\
\hline 17 & 39 & 11 & 1,0 & 10ДЗ+ЯЗ+ЛПД & 0043 & 160 & 2 & $\mathrm{C}_{3}$ ЛДС & 0,6 & 280 \\
\hline 18 & 55 & 10 & 4,1 & 8С32Д3 & 0043 & 150 & 1 & $\mathrm{C}_{2}$ ЛДС & 0,6 & 410 \\
\hline
\end{tabular}

*Примітка. Категорія особливо захисної лісової ділянки (ОЗЛД): ООЧЗ - Лісові ділянки на особливо охоронних частинах заказників, ЯБРД - Лісові ділянки у ярах, балках і річкових долинах, БЗЛД - Берегозахисні лісові ділянки. 
161,8 га, Низівське - 157,1 га, Піщанське - 282,8 га, Сумське - 158,7 га. До лісопаркової частини лісів зелених зон віднесено 3458,9 га: Низівське - 130,4 га, Піщанське - 2088,5 га, Сумське - 1240,0 га. До лісів в межах населених пунктів віднесено 836,6 га: Низівське - 27,6 га, Піщанське - 8,1 га, Сумське - 800,9 га.

У Низівському лісництві $є$ рекреаційний пункт та ставок (0,4 га), у Могрицькому - кемпінг у 116-річному сосновому насадженні (0,5 га).

Пам'яткам природи місцевого значення «Джерело Барвінкове-1», «Джерело Барвінкове-2» та «Джерело Вакалівське» можна також надати статус ОЦ3 5 (цінність - забезпечення невиснажливого рекреаційного використання території) та ОЦЗ 6 (цінність - збереження самовитічного джерела води).

Лісові території для збереження ОЦЗ 6. Культурні цінності наведені у табл. 3 .

За даними табл. 3 до ОЦЗ 6 Культурні цінності віднесено лісові ділянки у розрізі підкатегорій: «рекреаційний пункт (місце відпочинку)» - 3 об'єкта (загальною площею 0,83 га), «криниця» - 4 об'єкта (0,05 га), «джерело» 2 об'єкта (1,02 га), «пам'ятка археології / пам'ятка історії / об'єкт археології / могильник / поселення / городище» 8 об'єктів, «місце поховання» - 4 об'єкта, «Пам'ять загиблим солдатам» - 1 об'єкт.
Обговорення. Інституційні заходи, які вже застосовувалися у країнах Європи для досягнення цілей підтримки, збереження та покращення біорізноманіття лісів, зосереджуються, серед іншого, на вдосконаленні планування управління лісами з точки зору біорізноманіття, збереженні лісів з високою цінністю біорізноманіття та на посиленій координації та співпраці між відповідними відомствами з питань біорізноманіття, а також на збереженні лісових генетичних ресурсів. Основними проблемами та перешкодами для підтримання та належного посилення біологічного різноманіття в лісових екосистемах $€$ встановлення збалансованого та більш ефективного сталого захисту біотопів та видів, одночасно зі стійким використанням лісових ресурсів, застосування більш вимогливих систем господарювання, відсутність конвергенції між цілями охорони природи та цілями лісової політики (FOREST EUROPE, 2020).

Науковцями було проаналізовано звіти аудитів за схемами FSC та PEFC, оцінено частки сертифікованих лісових площ на державних та приватних землях із темпами їхнього приросту. Створено «Карту сертифікованих лісів Європи» на території 43 європейських держав. Відмічено, що в цілому у світі показник щорічного приросту площі сертифрікованих лісів є досить постійним (Maesano et al., 2018).

\section{Лісові території для збереження ОЦЗ 6}

\begin{tabular}{|c|c|c|c|c|c|}
\hline Лісництво & Кв./вид. & Площа, га & Склад & $\begin{array}{c}\text { Bik, } \\
\text { pokiв }\end{array}$ & Критерії виділення \\
\hline \multicolumn{6}{|c|}{ Рекреаційний пункт } \\
\hline Низівське & 9/22 & 0,4 & Ставок & & Рекр. пункт \\
\hline Піщанське & 9/6 & 0,4 & 10Дз+Бп+Клг+Лпд & 88 & Рекр. пункт \\
\hline Піщанське & $113 / 1$ & 0,03 & ЗДзЗЯз2Клг2Лпд+Бп+Ос & 102 & Рекр.пункт \\
\hline \multicolumn{6}{|c|}{ Криниці } \\
\hline Сумське & $66 / 27$ & 0,02 & 8Влч2Лпд+Клг+Ос & 87 & Криниця \\
\hline Сумське & $93 / 5$ & 0,01 & 5Влч5Врбб+Клг & 97 & Криниця \\
\hline Низівське & $48 / 9$ & 0,01 & 7ТкЗОс+Влч & 58 & Криниця \\
\hline Піщанське & $58 / 4$ & 0,02 & Біополяна & 62 & Криниця «Гарматський сад» \\
\hline \multicolumn{6}{|c|}{ Джерело } \\
\hline Низівське & $79 / 3$ & 0,02 & ЗДзЗБрс2Лпд2Яз+Ос+Бп & 82 & «Джерело Барвінкове-2» \\
\hline Піщанське & $123 / 17,26$ & 1,0 & 10Влч & 57 & «Джерело Вакалівське» \\
\hline \multicolumn{6}{|c|}{ Пам'ятка археології / пам'ятка історії / об'єкт археології / могильник / поселення / городище } \\
\hline Сумське & \multirow{2}{*}{\multicolumn{2}{|c|}{$\begin{array}{l}\text { КВ. } 108 \\
\text { KB. } 14\end{array}$}} & \multicolumn{3}{|c|}{ Пам'ятка археологї̈, поселення } \\
\hline Низівське & & & \multicolumn{3}{|c|}{ Пам'ятка археології, могильник грунтовий } \\
\hline Низівське & \multicolumn{2}{|c|}{ кв. $8,9,10,11$} & Пам'ятка археології, гор & це, сели & могильник IX-XIII ст.. \\
\hline Піщанське & \multicolumn{2}{|c|}{ кв. 82} & \multicolumn{3}{|c|}{ Об'єкт археології / курганний могильник поселення } \\
\hline Піщанське & \multirow{2}{*}{\multicolumn{2}{|c|}{ Кв. 145,144}} & \multicolumn{3}{|c|}{ Пам'ятка історії / городище «Битиця 1» } \\
\hline Піщанське & & & \multicolumn{3}{|c|}{ Пам'ятка історії / городище «Битиця 2» } \\
\hline Піщанське & \multirow{2}{*}{\multicolumn{2}{|c|}{$\begin{array}{c}\text { КВ. } 123,124,118,119 \\
\text { КВ. } 81,84,85,87\end{array}$}} & \multicolumn{3}{|c|}{ Пам'ятка історії/ городище «Вакалівщина» } \\
\hline Піщанське & & & Пам'ятка історії / городище & ище, кур & нний могильник IX-XIII ст. \\
\hline \multicolumn{6}{|c|}{ Місце поховання } \\
\hline Піщанське & $49 / 2$ & 0,01 & 5Яз1Дз2Клг2Лпд+Бп+Ос+Брс & 43 & Могила \\
\hline Піщанське & $135 / 5$ & 0,01 & Ставок & & Могила \\
\hline Піщанське & $137 / 12$ & 0,01 & 7Дз2Яз1Клг+Ос+Лпд+Брс & 98 & Могила \\
\hline \multicolumn{6}{|c|}{ Пам'ять загиблим солдатам } \\
\hline Піщанське & $7 / 23$ & 0,01 & 10Влч+Бп+Сз & 77 & 7 \\
\hline
\end{tabular}


У Словаччині власники лісів достатньо обізнані про цілі сталого лісового менеджменту та сприймають сертифікацію лісів як допоміжний інструмент для контролю за наданням екосистемних послуг. Це має прояв у моніторингу: ерозійних процесів, умов формування ґрунтів та складу деревостанів (має бути наближеним до природного), видового та екосистемного різноманіття, з подальшим забезпеченням естетичних, наукових та освітніх цінностей. У випадку великих лісових площ, сертифіковані компанії під час вибору надають перевагу забезпеченню таких екосистемних послуг як продукування деревної біомаси та накопичення води (Paluš et al., 2021).

Концепція ОЦЗ була запропонована під час процесу сертифікації лісів задля систематичного виявлення біорізноманіття та екосистемних послуг, що надаються лісовими екосистемами, але ця концепція набула більш широкого розвитку - для виокремлення лісів, важливих для збереження біорізноманіття (Mikusiński et al., 2021).

Більшість країн мають спільні передумови та перешкоди для застосування концепції ОЦЗ на національних рівнях. Детально це питання висвітлено у роботі С. Галстян (Galstyan, 2017) для Республіки Вірменія. Слід зазначити, що наведений підхід $€$ актуальним для ситуації у багатьох країнах. До передумов застосування концепції ОЦЗ на національному рівні належить наявність інформації: Червона книга; перелік ендемічних видів рослин і тварин; об'єкти природно-заповідного фонду; перелік оселищ, лісові території, які були запропоновані до Смарагдової мережі (Emerald Network); важливі території для рослин (Important Plant Areas - IPA) та важливі території для птахів (Important Bird Areas - IBA); пріоритетні території для збереження (Priority Conservation Areas PCAs); результати інвентаризації лісів та біорізноманіття та плани управління; результати соціально-економічних досліджень представників тих громад, які мешкають у лісі або поріч із ним. До перешкод концепції ОЦЗ на національному рівні належить: відсутність актуальної інформації про наявність цінностей для збереження у лісах; упущення у національних правових рамках, політиці та стратегії лісового господарства; відсутність затверджених національних критеріїв ідентифрікації лісів із особливими цінностями; конфрлікт із існуючим плануванням землекористування. Наведені перешкоди потрібують вирішення. Крім того, необхідно продовжувати польові дослідження щодо розподілу видів Червоної книги та їх переоцінки за критеріями МCOП (IUCN), а також щодо ідентифікації рідкісних лісових біотопів.

Ньюйоркський державний департамент охорони довкілля є утримувачем сертифікату (за 2015-2019 SFI Standart@). Звіт аудиту 2017 року (New York State, 2018) стосовно лісового менеджменту проводився за 6 напрямами: планування системи ведення лісового господарства; здоров'я лісу та продуктивність; захист та підтримка водних ресурсів; збереження біологічного різноманіття; управління візуальною якістю та рекреаційними перевагами; захист особливих місць. У напрямку збереження біологічного різноманіття перевага надавалася управлінню якістю та поширенням місць оселень дикої природи та взяттю участі у збереження біологічного різно- маніття шляхом розвитку та імплементації заходів на рівні лісостану та на рівні природного ландшафту, які б сприяли різноманіттю типів місць оселень та суксесійних стадій та збереженню лісових рослин та тварин, у т ч. й водних видів, старовікових лісів та екологічно важливих місць, лісу з винятковою цінністю для збереження (англ. Forest with Exceptional Conservation Value FECV), За результатами оцінки розробляються стратегії щодо збереження біорізноманіття із обов'язковим занесенням даним до матеріалів лісовпорядкування. Ліс 3 винятковою цінністю для збереження виділяється окремою категорією, яка входить до складу лісів з високою цінністю для збереження (англ. High Conservation Value Forest - HCVF). Різні типи HCVF символічно позначаються на планах певним кольором: рідкісні угруповання - червоним кольором, територія із особливим доглядом - пурпурним, водоохоронні території - блакитним. Методологією передбачається включення результатів досліджень та польових чек-листів щодо оцінки стану біорізноманіття та екосистеми до рішень лісоуправління.

Науковці із Швеції провели широкомасштабне дослідження щодо оцінки просторового розміщення та перекриття контурів квазі-пралісових лісів, які не були ідентифіковані як ліси із ОЦЗ, а також контурів лісів із виявленими ОЦЗ (HCVF). Доведено, що додавання контурів таких квазі-пралісових лісів до мережі лісів із ОЦЗ створює мережу захищених лісів та збільшує структурний зв'язок між ними. За рахунок наведеного процесу площа середовища існування видів із незначною вимогливістю (залежать від ялинових або соснових лісів), може бути значно збільшеною. Для видів видів із значною вимогливістю необхідним є додаткове відновлення оселищ (у ландшафтній матриці) (Mikusiński et al., 2021).

Індонезійська державна компанія Perum Perhutani здійснює лісоуправління на островах Ява і Мадура. Ця компанія провела ідентифікацію ОЦЗ з метою підтримання сталості користування лісовими ресурсами та виконання функцій лісів. Було виявлено усі категорії ОЦЗ. Слід відмітити, що у багатьох випадках на певних територіях були виявлені декілька ОЦЗ одночасно. Наприклад, у буферній зоні між національними природними парками (ОЦЗ 1.1) є місця перебування охоронюваного виду леопарда (Pantera pardus melas) (ОЦ3 1.2) або ж місця оселення ендемічного виду сімейства мавп - блискучого гульмана (Trachypithecus auratus). До ОЦЗ 3 віднесені регіони із високим рівнем біорізноманіття, ОЦЗ 4 - береги річок та водні струмки, ОЦЗ 5 - місця сбору паливної деревини та заготівлі сіна, ОЦЗ 6 - 16 культурних місць. На думку індонезійських дослідників моніторинг та ОЦЗТ даних свідчить про підвищення рівня збереженості флори і фрауни (Sri \& Sudharto, 2018).

Нині здійснено вагомі дослідження в Українських Карпатах щодо важливості та значення старовікових лісів і пралісів, історії їхніх досліджень та збереження, правового статусу та критеріїв для виділення цих лісів в Україні (Grebener et al., 2018).

У лісогосподарських підприємствах України зібрано достатньо різноманітної інформації, необхідної для виділення ОЦЗ різних категорій - є дані про природно-заповідний фонд, захисні ліси, місця оселень тварин зростання 
рослин, занесених до «Червоної книги України», про об'єкти традиційної культурної ідентичності громади. Державним підприємствам, які мають сертифрікат FSC ведення лісового господарства, заготовляють чи переробляють чи реалізовують деревину слід проводити спеціальні дослідження щодо виділення лісових територій із ОЦЗ, оскільки раніше такі дослідження не проводилися.

Для полегшення дотримання підприємствами принципів і критеріїв відповідального управління лісами був розроблений «Посібник з питань практичної реалізації FSC національного стандарту системи ведення лісового господарства для України» (Posibnyk z pytan', 2021).

Відповідно до вимог критеріїв Принципу 9 «Особливі цінності для збереження» спеціалісти лісового господарства мають розробити та впровадити у практику ефективні стратегії щодо підтримки та збереження виявлених ОЦЗ, визначення наявних на території підприємства загрози для цих цінностей. До цього процесу мають долучатися сторони, чиї інтереси зачеплено (Kremenec'ka \& Cherepovs'kyj, 2021).

Висновки. В Україні, методичні підходи щодо виконання вимог Принципу 9 «Особливі цінності для збереження» добровільної лісової сертифрікації за схемою FSC $₫$ являють собою поєднання міжнародних та національних вимог, пов'язаних із збереженням лісових територій із різними особливими цінностями для збереження (ОЦ3): видового різноманіття, екосистем та оселищ, критичних послуг екосистем, потреб громади, культурних цінностей. Ідентифрікація ОЦЗ 1.1 Природно-запо- відні території не була складною, вона включає 9 існуючих об'єктів, в т. ч.: 2 заказники загальнодержаного значення, 4 заказники та 3 пам'ятки природи місцевого значення. Ідентифікація ОЦЗ 1.2 Види, що перебувають під загрозою знищення, вимирають та ендемічні види вимагає ґрунтовних знань щодо природоохоронного статусу рослин та тварин, які зростають / мешкають на певній території. ОЦЗ 1.3 Ключові сезонні місия концентрації тварин були виділені, потребують подальшого вивчення у польових умовах. Ідентифікація ОЦЗ 3 Екосистеми та оселища виявилася найскладнішою, оскільки здатність виявляти лісові території, що містять зникаючі, рідкісні та вразливі біотопи потребує додаткових знань у сфері сучасних методик та інформації щодо виділення: старовікових лісів, рослинних угруповань із «Зеленої книги України», IBA-територій та багато іншого. Ідентифрікація ОЦЗ 5 Потреби громади та ОЦЗ 6 Культурні цінності не викликала ускладнень, вона потребує консультації із зацікавленими сторонами. Ідентифікацію ОЦЗ на лісових територіях слід здійснювати відповідно до Національного стандарту системи ведення лісового господарства для України. Запропоновані методичні підходи та результати ідентисрікації ОЦЗ є своєрідними інструментами реалізації завдань лісової політики щодо сталого ведення лісового господарства. В подальшому, наявність банку даних щодо ідентифікованих ОЦЗ на лісових територіях України, дозволять нашій країні приєднатися до зеленої інфраструктури Європи.

\section{Бібліографічні посилання:}

1. Aleksijuk, I. L. (2019). Vysnovky pro rezul'taty provedennja pol'ovyh doslidzhen' ta zavershal'nogo etapu vyznachennja nalezhnosti lisovyh terytorij do pralisiv, kvazipralisiv i pryrodnyh lisiv na terytorii' derzhavnogo pidpryjemstva «Sums'ke lisove gospodarstvo». [Conclusions on the results of field research and the final stage of determining the affiliation of forest areas to virgin, quasi-virgin and natural forests on the territory of the state enterprise «Sumy Forestry»]. Kyi'v: Ministerstvo ekologii' ta pryrodnyh resursiv Ukrai'ny, derzhavne pidpryjemstvo «Biologichni resursy Ukrai'ny» (in Ukrainian).

2. Andrijenko, T. L. \& Peregrym, M. M. (2012). Oficijni pereliky regional'no ridkisnyh roslyn administratyvnyh terytorij Ukrai'ny (dovidkove vydannja) [Official lists of regionally rare plants of administrative territories of Ukraine (reference edition)]. Kyi'v, 104-112 (in Ukrainian). Access mode: https://www.botany.kiev.ua/doc/of_reg_sp.pdf

3. Bondaruk, G. V. \& Buksha, I. F. (2010). Rekomendacii' z lisovoi' sertyfikacii' lisogospodars'kyh pidpryjemstv. [Recommendations for forest certification of forestry enterprises]. Ukrai'ns'kyj naukovo-doslidnyj instytut lisovogo gospodarstva ta agrolisomelioracii', Harkiv, 73 (in Ukrainian).

4. Bondaruk, G. V., Kagalo, O. O., Procenko, L. D., Artov, A. M. \& Proc', B. G. (2013). Normatyvno-pravove zabezpechennja zberezhennja bioriznomanittja $v$ lisovomu sektori Ukrai'ny: analiz ta perspektyvy rozvytku [Normative and legal support of biodiversity conservation in the forest sector of Ukraine: analysis and prospects of development]. L'viv, 266 (in Ukrainian).

5. Chatzimentor, A., Apostolopoulou, E. \& Mazaris, A. D. (2020). A review of green infrastructure research in Europe: challenges and opportunities. Landscape Urban Plan., 198:103775. doi: 10.1016/j.landurbplan.2020.103775

6. Chazdon, R. L. (2017). Landscape restoration, natural regeneration, and the forests of the future. Ann. Mo. Bot. Gard. 102, 251-257. doi: 10.3417/2016035

7. Chervona knyga Ukrai'ny. Roslynnyj svit / za red. Ja. P. Diduha (2009). [Red Book of Ukraine. Flora / ed. J. P. Didukha]. Kyi'v, 900 (in Ukrainian). Access mode: http://helium.pp.ua/site/library/dovidnyky/chervona-knyga-roslynnyi-svit-diduh.html

8. Chervona knyga Ukrai'ny. Tvarynnyj svit / za red. I. A. Akimova (2009). [Red Book of Ukraine. Fauna / ed. I. A. Akimova]. Kyi'v, 600 (in Ukrainian). Access mode: https://www.studmed.ru/akmov-ared-chervona-kniga-ukrayinitvarinniy-svt_5ea5251f0f3.html

9. Curtis, P. G., Slay, C. M., Harris, N. L., Tyukavina, A. \& Hansen, M. C. (2018). Classifying drivers of global forest loss. Science, 361, 1108-1111. doi: 10.1126/science.aau3445

10. Derzhavnyj kadastr terytorij ta ob'jektiv pryrodno-zapovidnogo fondu Ukrai'ny (2019) [State cadastre of territories and objects of the nature reserve fund of Ukraine] (in Ukrainian). Access mode: http://pzf.menr.gov.ua/пзфр-україни/території-та-об'єкти-пзф-україни.html

11. Dopovid' pro stan navkolyshn'ogo pryrodnogo seredovyshha v Sums'kij oblasti u 2017 roci [Report on the state of the environment in Sumy region in 2017]. (2018). Sums'ka oblasna derzhavna administracija, Sumy, 223 (in Ukrainian).

12. Dubovich, I. A., Vasylyshyn, H. R., Fomicheva, T. Je. \& Volkovs'ka, Ju. I. (2019). Ekonomiko-pravove reguljuvannja ohorony ta zberezhennja bioriznomanittja ekosystem: teorija i praktyka [Economic and legal regulation of protection and 
conservation of ecosystem biodiversity: theory and practice]. Naukovi praci Lisivnychoi' akademii' nauk Ukrai'ny, 19, 178-186 (in Ukrainian). doi: 10.15421/411940

13. Dzhennyngs, S., Nussbaum, R., Dzhadd, N. \& Jevans, T. (2005). Lesa vysokoj prirodoohrannoj cennosti. Prakticheskoe rukovodstvo. perevod s anglijskogo. [High conservation value forests. Practical guide. translated from English], 184 (in Russian). Access mode: http://213.189.208.206/hcvf/publications/LVPC_prakticheskoe\%20rukovodstvo_Dzhennings.pdf

14. Evaluating Conservation Gains in North America through HCVF Assessments (Report Prepared for World Wildlife Fund - Canada) by Marcelo Levy\&Nick Moss Gillespie Responsible Forestry Solutions (March 2007) WWF-Canada Evaluating Conservation Gains in North America Through HCVF Assessments, Final Report. 31.

15. FOREST EUROPE, 2020: State of Europe's Forests 2020. Criterion 4: Maintenance, Conservation and Appropriate Enhancement of Biological Diversity in Forest Ecosystems, 110-148. Indicator C.4: Policies, institutions and instruments to maintain, conserve and appropriately enhance the biological diversity in forest ecosystems, 147. Access mode: https:// foresteurope.org/wp-content/uploads/2016/08/SoEF_2020.pdf

16. FSC nacional'nyj standart systemy vedennja lisovogo gospodarstva dlja Ukrai'ny (FSC-STD-UKR-01-2019 V 1-0 (nabuv chynnosti z 30 bereznja 2020 r.) [FSC national standard of forestry system for Ukraine (FSC-STD-UKR-01-2019 V 1-0 entered into force on March 30, 2020)] (in Ukrainian). Access mode: https://ua.fsc.org/preview.fsc-std-ukr-01-2019v-1-0-fsc.a-1013.pdf

17. Forest Stewardship Council A.C., 2000, 10.

18. Galstyan S. (2017). Prerequisites and obstacles for application of the concept of high conservation value forests in Armenia / Annals of Agrarian Science, 15 295-299. doi: 10.1016/j.aasci.2017.07.001

19. Gorban' I. M., Zatushevs'kyj, A. T. \& Matejchyk V. I. (2009). Pro osoblyvo cinni lisy dlja zberezhennja landshaftnogo ta biologichnogo riznomanittja [About high conservation value forests for preservation of landscape and biological diversity]. Naukovyj visnyk Volyns'kogo nacional'nogo universytetu imeni Lesi Ukrai'nky, 2, 37-41 (in Ukrainian). Access mode: http:/l nbuv.gov.ua/UJRN/Nvvnu_2009_2_8

20. Grebener, U., Knapp, G. D., Proc', B., Smalijchuk, A. \& Volosjanchuk R. Pryrodni lisy Ukrai'ns'kyh Karpat / red. A. Smalijchuk ta U. Grebener (2018) [Natural forests of the Ukrainian Carpathians / ed. A. Smaliychuk \& U. Grebener]. L'viv, 104 (in Ukrainian).

21. Interaktyvni karty Smaragdovoi' merezhi Ukrai'ny. [Interactive maps of the Emerald Network of Ukraine] Access mode: http://emerald.net.ua

22. Jonsson, B. G., Svensson, J., Mikusin' ski, G., Manton, M. \& Angelstam, P. (2019). European Union's last intact forest landscapes are at a value chain crossroad between multiple use and intensified wood production. Forests, 10, 564. doi: $10.3390 / f 10070564$

23. Karpuk, A.I., Morozjuk, O.V., Tokareva, O.V., Tyshhenko, V.M., Kremenec'ka, Je.O., Churilov, A.M., Shevchuk, O.V., Dubrovec', B.V. \& Nevmerzhyc'kyj, V.I. (2015). Metodychni rekomendacii' z vydilennja, monitoryngu ta ohorony osoblyvo cinnyh dlja zberezhennja lisiv. [Guidelines for the identification, monitoring and protection of high conservation value forests]. Kyi'v, 43 (in Ukrainian). Access mode: http://sfmu.org.ua/files/METODYCHNI-REKOMENDACII-Z-VYDILENNJAMONITORYNGU-TA-OHORONY-OCZL.pdf).

24. Konvencija pro ohoronu biologichnogo riznomanittja (Rio-de-Zhanejro 1992 rik). Zakon pro ratyfikaciju Konvencii' vid 29 lystopada 1994 roku № 257/94-VR [Convention on Biological Diversity (Rio de Janeiro 1992). Law on Ratification of the Convention of 29 November 1994 № 257/94-VR] (in Ukrainian). Access mode: https://zakon.rada.gov.ua/laws/show/995_030

25. Konvencija pro ohoronu dykoi' flory ta fauny ta pryrodnyh seredovyshh i'h isnuvannja v Jevropi. (Bern 1979 rik). Zakon pro pryjednannja Ukrai'ny do Konvencii' 1979 roku pro ohoronu dykoi' flory ta fauny ta pryrodnyh seredovyshh i'h isnuvannja v Jevropi vid 29 zhovtnja 1996 r. №436/96-VR. [Convention on the Conservation of European Wildlife and Natural Habitats. (Bern 1979). Law on Ukraine's Accession to the 1979 Convention on the Conservation of European Wildlife and Natural Habitats of 29 October 1996 № 436/96-VR] (in Ukrainian). Access mode: https://zakon.rada.gov.ua/ laws/show/995_032

26. Konvencija pro vodno-bolotni ugiddja, shho majut' mizhnarodne znachennja, golovnym chynom jak seredovyshha isnuvannja vodoplavnyh ptahiv (Ramsar 1971 rik). Zakon Ukrai'ny pro uchast' u Konvencii' vid 29 zhovtnja 1996 r. №437/96VR. [Convention on Wetlands of International Importance, Mainly as Habitats for Waterfowl (Ramsar 1971). Law of Ukraine on Participation in the Convention of October 29, 1996 №437 / 96-VR] (in Ukrainian). Access mode: https://zakon.rada.gov. ua/laws/show/995_031

27. Konvencija pro zberezhennja migrujuchyh vydiv dykyh tvaryn (Bonn 1979 rik), Zakon Ukrai'ny pro pryjednannja do Konvencii' vid 19 bereznja 1999 roku № 535-XIV. [Convention on the Conservation of Migratory Species of Wild Animals (Bonn 1979), Law of Ukraine on Accession to the Convention of 19 March 1999 № 535-XIV] (in Ukrainian). Access mode: https://zakon.rada.gov.ua/laws/show/995_136

28. Kremenec'ka Je. O. \& Cherepovs'kyj M. V. (2021) Novitni pidhody u sferi upravlinnja lisogospodars'kym vyrobnyctvom shhodo vyrishennja ekologichnyh problem vidpovidno do vymog lisovoi' sertyfikacii' za shemoju FSC $\AA_{\text {[The }}$ latest approaches in the field of forest management to solve environmental problems in accordance with the requirements of forest certification under the FSC $\circledast$ scheme] «Goncharivs'ki chytannja»: Materialy Mizhnarodnoi' naukovo-praktychnoi' konferencii', prysvjachenoi' 92 richchju z dnja narodzhennja doktora sil's'kogospodars'kyh nauk, profesora Goncharova Mykoly Dem'janovycha (25 travnja 2021 r.). SNAU, Sumy, 140-143 (in Ukrainian).

29. Lesa vysokoj prirodoohrannoj cennosti: koncepcija v teorii ina praktike (2009). [High conservation value forests: concept in theory and in practice]. Vsemirnyj fond dikoj prirody (WWF), 178-186 (in Russian). Access mode: http://213.189.208.206/ hcvf/publications/LVPC\%20koncepcija.pdf 
30. Liquete, C., Kleeschulte, S., Dige, G., Maes, J., Grizetti, B., Olah, B. \& Zulian, G. (2015). Mapping green infrastructure based on ecosystem services and ecological networks: a Pan-European case study. Environ. Sci. Policy, 54, 268-280. doi: 10.1016/j.envsci.2015.07.009

31. Lisovyj kodeks Ukrai'ny. [Forest Code of Ukraine]. (in Ukrainian). Access mode: https://zakon.rada.gov.ua/laws/ show/ru/3852-12

32. Maesano, M., Ottaviano, M., Lidestav, G., Lasserre, B., Matteucci, G., Scarascia Mugnozza, G., Marchetti, M. (2018). Forest certification map of Europe. iForest, 11, 526-533. doi: 10.3832/ifor2668-011

33. Mikusiński, G., Orlikowska, E. H., Bubnicki, J. W., Jonsson, B. G. \& Svensson, J. (2021). Strengthening the Network of High Conservation Value Forests in Boreal Landscapes. Front. Ecol. Evol. 8:595730. doi: 10.3389/fevo.2020.595730

34. Morozjuk, O. V., Dubrovec', B. V. \& Nevmerzhyc'kyj, V. I. (2015). Osoblyvosti pravovogo zabezpechennja vydilennja lesov osoblyvo cinnyh dlja zberezhennja lisiv v Ukrai'ni. [Features of legal support for the identification of high conservation value forests in Ukraine]. Naukovi praci Lisivnychoi' akademii' nauk Ukrai'ny, 193, 144-148 (in Ukrainian)

35. Mykytjuk, O. Ju. (1999) IBA terytorii' Ukrai'ny: terytorii', vazhlyvi dlja zberezhennja vydiv riznomanittja ta kil'kisnogo bagatstva ptahiv. [IBA of the territory of Ukraine: territories important for the conservation of species diversity and quantitative wealth of birds]. Kyi'v, 324 (in Ukrainian).

36. Nacional'nyj katalog biotopiv Ukrai'ny [National Catalog of Habitats of Ukraine] (2018). Za red. A.A. Kuzemko, Ja.P. Diduha, V.A. Onyshhenka, Ja. Sheffera. Kyi'v, 442 (in Ukrainian).

37. Nghobuoche, F., Ngoufo, R., Tatuebu, T., C., Louis, D. \& Kiming, I. N. (2020). Forest Certification for Sustainable Forest Management in Cameroon: Myth or Reality. International Journal of Environmental Protection and Policy, 8(6), 105-116. doi: 10.11648/j.ijepp.20200806.11

38. New York State Department of Environmental Conservation (NYDEC) 2017 SFI Forest Management Public Summary Report. 2018, 58. Access mode: https://www.dec.ny.gov/docs/lands_forests_pdf/2017sfifmfinalaudit_1_.pdf

39. Osoblyvo cinni dlja zberezhennja lisy: vyznachennja ta gospodarjuvannja. (2008). Praktychnyj posibnyk WWF dlja Ukrai'ny. [High conservation value forests: identification and management. WWF Practical Guide for Ukraine], 146 (in Ukrainian). Access mode: https://d2ouvy59p0dg6k.cloudfront.net/downloads/oczl.pdf).

40. Paluš, H., Krahulcová, M., \& Parobek, J. (2021)Assessment of forest certification as a tool to support forest ecosystem services. Forests, 12, 300.

41. Patru-Stupariu, I., Angelstam, P., Elbakidze, M., Huzui, A. \& Andersson, K. (2013). Using forest history and spatial patterns to identify potential high conservation value forests in Romania. Biodivers. Conserv., 22, 2023-2039. doi: 10.1007/ s10531-013-0523-3

42. Plan lisonasadzhen' DP «Sums'kyj lisgosp» Mogryc'ke lisnyctvo Sums'ka oblast'. Zagal'na ploshha 6838,3 ga. Lisovporjadkuvannja 2017 roku. Masshtab 1:25000. (2017). [Plan lisonasadzhen DP «Sumskiy lisgosp» Mogrytske lisnitsvo Sumsk region. Zagalna area of 6838.3 hectares. Lisovorodkuvannya 2017 rock. Scale 1: 25000] (in Ukrainian).

43. Plan lisonasadzhen' DP «Sums'kyj lisgosp» Pishhans'ke lisnyctvo Sums'ka oblast'. Zagal'na ploshha 8049,5 ga. Lisovporjadkuvannja 2017 roku. Masshtab 1:25000. (2017). [Plan lisonasadzhen DP «Sumy lisgosp» Pishchanske lisnitsvo Sumsk region. Zagalna area is 8049.5 hectares. Lisovorodkuvannya 2017 rock. Scale 1: 25000] (in Ukrainian).

44. Plan lisonasadzhen DP "Sumy lisgosp" Nizivske lisnitstvo Sumsk region. Zagalna area is 8049.5 hectares. Lisovorodkuvannya 2017 rock. Scale 1: 25000. (2017). [Plan lisonasadzhen' DP «Sums'kyj lisgosp» Nyzivs'ke lisnyctvo Sums'ka oblast'. Zagal'na ploshha 8049,5 ga. Lisovporjadkuvannja 2017 roku. Masshtab 1:25000] (in Ukrainian).

45. Plan lisonasadzhen' DP «Sums'kyj lisgosp» Sums'ke lisnyctvo Sums'ka oblast'. Zagal'na ploshha 8049,5 ga. Lisovporjadkuvannja 2017 roku. Masshtab 1:25000. (2017). [Plan lisonasadzhen DP "Sumskiy lisgosp" Sumske lisnitsvo Sumsk region. Zagalna area is 8049.5 hectares. Lisovorodkuvannya 2017 rock. Scale 1: 25000] (in Ukrainian).

46. Porjadok podilu lisiv na kategorii' ta vydilennja osoblyvo zahysnyh lisovyh diljanok. [The procedure for dividing forests into categories and allocating specially protected forest areas]. Access mode: https://zakon.rada.gov.ua/laws/ show/733-2007-\%D0\%BF

47. Posibnyk z pytan' praktychnoi' realizacii' FSC $\Omega$ nacional'nogo standartu systemy vedennja lisovogo gospodarstva dlja Ukrai'ny. Kolektyv rozrobnykiv posibnyka: Bondaruk G. V. - pryncypy 8, 9; Volosjanchuk R. T. - pryncyp 6; Kremenec'ka Je. O. - pryncyp 8; Obors'ka A. E., Kovalyshyn V. R. - pryncypy 7, 10; Pavlishhuk O. P. - vstup, zagal'na chastyna, pryncyp 4; Rozvod S. V. - pryncyp 5; Caruk O. I. - pryncypy 1, 2. / Pid zagal'noju redakcijeju Kravcja P.V. [Guide to the practical implementation of the FSC $₫$ national standard of forestry system for Ukraine / ed. P. V. Kravets]. Kyi'v: FSC Ukrai'na, 2021, 171 (in Ukrainian).

48. Potapov, P., Hansen, M. C., Laestadius, L., Turubanova, S., Yaroshenko, A., Thies, C., Smith, W., Zhuravleva, I., Komarova, A., Minnemeyer, S. \& Esipova, E. (2017). The last frontiers of wilderness: tracking loss of intact forest landscapes from 2000 to 2013. Sci. Adv., 3:1600821. doi: 10.1126/sciadv.1600821

49. Proc', B., Papp, K., Vlad, R., Bashta, A.-T., Kagalo, O., Kish, R., Beresh, M. \& Badaryu, A. (2014). Praktychnyj posibnyk dlja vyznachennja ta upravlinnja lisamy, jaki vkljuchajut' vazhlyvi oseredky vydovogo riznomanittja u Marmaros'komu transkordonnomu regioni (Rumunija-Ukrai'na). [A practical guide to identifying and managing forests that include important species habitats in the Marmara transboundary region (Romania-Ukraine)]. L'viv, 62 (in Ukrainian). Access mode: http://sfmu.org.ua/files/WWF_Ghid\%20Specii_UA.pdf

50. Proekt organizacii' ta rozvytku lisovogo gospodarstva derzhavnogo pidpryjemstva "Sums'ke lisove gospodarstvo" Sums'kogo oblasnogo upravlinnja lisovogo ta myslyvs'kogo gospodarstva Derzhavnogo agentstva lisovyh resursiv Ukrai'ny. Pojasnjuval'na zapyska (2018). [Project of organization and development of forestry of the state enterprise "Sumy forestry" of the Sumy regional management of forestry and hunting of the State agency of forest resources of Ukraine. Explanatory note]. Ukrai'ns'ke derzhavne proektne lisovporjadne vyrobnyche ob'jednannja "Ukrderzhlisproekt”, Irpin', 159 (in Ukrainian). 
51. Proekt organizacii' ta rozvytku lisovogo gospodarstva derzhavnogo pidpryjemstva "Sums'ke lisove gospodarstvo" Sums'kogo oblasnogo upravlinnja lisovogo ta myslyvs'kogo gospodarstva. Mogryc'ke lisnyctvo. Taksacijnyj opys, vidomosti pokvartal'nyh pidsumkiv. (2018). [Project of organization and development of forestry of the state enterprise "Sumy forestry" of the Sumy regional management of forestry and hunting. Mogritske forestry department. Forest inventory materials, information on quarterly results]. Ukrai'ns'ke derzhavne proektne lisovporjadne vyrobnyche ob’jednannja „Ukrderzhlisproekt”, Irpin', 301 (in Ukrainian).

52. Proekt organizacii' ta rozvytku lisovogo gospodarstva derzhavnogo pidpryjemstva "Sums'ke lisove gospodarstvo" Sums'kogo oblasnogo upravlinnja lisovogo ta myslyvs'kogo gospodarstva. Nyzivs'ke lisnyctvo. Taksacijnyj opys, vidomosti pokvartal'nyh pidsumkiv. (2018). [Project of organization and development of forestry of the state enterprise "Sumy forestry" of the Sumy regional management of forestry and hunting. Nyzivs'ke orestry department. Forest inventory materials, information on quarterly results]. Ukrai'ns'ke derzhavne proektne lisovporjadne vyrobnyche ob’jednannja „Ukrderzhlisproekt”, Irpin', 248 (in Ukrainian).

53. Proekt organizacii' ta rozvytku lisovogo gospodarstva derzhavnogo pidpryjemstva "Sums'ke lisove gospodarstvo" Sums'kogo oblasnogo upravlinnja lisovogo ta myslyvs'kogo gospodarstva. Pishchans'ke lisnyctvo. Taksacijnyj opys, vidomosti pokvartal'nyh pidsumkiv. (2018). [Project of organization and development of forestry of the state enterprise "Sumy forestry" of the Sumy regional management of forestry and hunting. Pishchans'ke forestry department. Forest inventory materials, information on quarterly results]. Ukrai'ns'ke derzhavne proektne lisovporjadne vyrobnyche ob'jednannja „Ukrderzhlisproekt”, Irpin', 455 (in Ukrainian).

54. Proekt organizacii' ta rozvytku lisovogo gospodarstva derzhavnogo pidpryjemstva "Sums'ke lisove gospodarstvo" Sums'kogo oblasnogo upravlinnja lisovogo ta myslyvs'kogo gospodarstva. Sums'ke lisnyctvo. Taksacijnyj opys, vidomosti pokvartal'nyh pidsumkiv. (2018). [Project of organization and development of forestry of the state enterprise "Sumy forestry" of the Sumy regional management of forestry and hunting. Sumske forestry department. Forest inventory materials, information on quarterly results]. Ukrai'ns'ke derzhavne proektne lisovporjadne vyrobnyche ob’jednannja „Ukrderzhlisproekt”, Irpin', 420 (in Ukrainian).

55. Rejestr pam jatok kul'turnoi' spadshhyny Ukrai'ny miscevogo znachennja. [Реєстр пам 'яток культурної спадщини України місцевого значення.]. Access mode: http://mincult.kmu.gov.ua/control/uk/publish/article?art_id=245323810\&cat_id=244910406

56. Rejestr pam jatok kul'turnoi' spadshhyny Ukrai'ny nacional'nogo znachennja. [Register of monuments of cultural heritage of Ukraine of national importance]. Access mode: http://mincult.kmu.gov.ua/control/uk/publish/article?art_ id $=245365203 \&$ cat id $=244910406$

57. Sabatini, F. M., Burrascano, S., Keeton, W. S., Levers, C., Lindner, M., Pötzschner, F., Verkerk, P. J., Bauhus, J., Buchwald, E., Chaskovsky, O., Debaive, N., Horváth, F., Garbarino, M., Grigoriadis, N., Lombardi, F., Duarte, I. M., Meyer, P., Midteng, R., Mikac, S., Mikoláš, M., Motta, R., Mozgeris, G., Nunes, L., Panayotov, M., Ódor, P., Ruete, A., Simovski, B., Stillhard, J., Svoboda, M.4 Szwagrzyk, J.; Tikkanen, O.-P.; Volosyanchuk, R.; Vrska, T.; Zlatanov, T. \& Kuemmerle, T. (2018). Where are Europe's last primary forests? Diversity and Distributions, 24:1426-1439. doi: 10.1111/ddi.12778

58. Shparyk, Ju., Chernjavs'kyj, M., Kagalo, O., Bondaruk, G., Ponepoljak, M., Forgil', Ja., Zelenchuk, Ja., Volosjanchuk, R. \& Proc', B. (2015). Kryterii' ta metodyka identyfikacii' starovikovyh lisiv i pralisiv. [Criteria and methods of identification of ancient forests and virgin forests]. L'viv, 28 (in Ukrainian).

59. Sri Sulistyowati \& Sudharto P. Hadi (2018). The existence of High Conservation Value Forest (HCVF) in Perum Perhutani KPH Kendal to support Implementation of FSC Certification E3S Web of Conferences 31, 08019 Section 08. Environmental Conservation. The 2nd International Conference on Energy, Environmental and Information System (ICENIS 2017). doi: 10.1051/e3sconf/20183108019

60. Standart FSC-NRA-UA V1-1FSC ocinka ryzyku kontrol'ovanoi' derevyny dlja Ukrai'ny (rozroblena zgidno z proceduroju FSC-PRO-60-002 V 3-0) [Standard FSC-NRA-UA V1-1FSC risk assessment of controlled wood for Ukraine (developed according to the procedure FSC-PRO-60-002 V 3-0)]. Data shvalennja: 15 grudnja 2017, 114 (in Ukrainian). Access mode: https://ua.fsc.org/ua-ua/nasha-diyalnist/-01

61. Sums'ke oblasne upravlinnja lisovogo ta myslyvs'kogo gospodarstva. [Sumy regional department of forestry and hunting]. Access mode: http://www.sumylis.gov.ua/napryamki-diyalnosti/prirodno-zapovidnij-fond.html

62. Svensson, J., Andersson, J., Sandström, P., Mikusin'ski, G. \& Jonsson, B. G. (2019). Landscape trajectory of natural boreal forest loss as an impediment to green infrastructure. Conserv. Biol., 33, 152-163. doi: 10.1111/cobi. 13148

63. Svensson, J., Bubnicki, J. W., Jonsson, B.-G., Andersson, J. \& Mikusin' ski, G. (2020). Conservation significance of intact forest landscapes in the Scandinavian mountains green belt. Landscape Ecol., 35, 2113-2131. doi: 10.1007/ s10980-020-01088-4

64. Tian, N.; Poudyal, N. \& Lu, F. (2021). Assessments of Landowners' Willingness to Accept Compensation for Participating in Forest Certification in Shandong, China. Sustainability, 13, 903. doi: 10.3390/su13020903

65. Ugoda pro zberezhennja kazhaniv v Jevropi (Bristol' 1995 r.) zakon Ukrai'ny pro pryjednannja do Ugody vid 14 travnja 1999 roku № 663-XIV [Agreement on the Conservation of Bats in Europe (Bristol 1995) Law of Ukraine on Accession to the Agreement of 14 May 1999 № 663-XIV] (in Ukrainian). Access mode: https://zakon.rada.gov.ua/laws/show/663-14)

66. Ukrai'ns'ka pryrodoohoronna grupa. Sajt. [Ukrainian Environmental Protection Group. Website]. Access mode: http://uncg.org.ua

67. Veb-karta starovikovyh lisiv Ukrai'ns'kogo Polissja [Web map of ancient forests of Ukrainian Polissya]. Access mode: https://scgis.org.ua/oldforests-light/

68. Vlad, R., Proc', B. \& Bukur, K. (2014). Posibnyk dlja vyznachennja osoblyvo cinnyh dlja zberezhennja lisiv u transkordonnomu regioni Marmaroshhyny (Rumunija-Ukrai'na) ta gospodarjuvannja $v$ nyh. [A guide to identifying and managing of high conservation value forests of the Marmara region (Romania-Ukraine)]. L'viv, 38 (in Ukrainian).

69. Vorob'ev, D. V. (1953) Tipy lesov Evropejskoj chast SSSR. [Types of forests in the European part of the USSR]. Kyev, 452 (in Russian).

70. Zelena knyga Ukrai'ny [Green Book of Ukraine] (2009). Pid zagal'noju redakcijeju Ja.P. Diduha. Kyi'v, 448 (in Ukrainian). 
Kremenetska Ye. O., PhD (Agricultural Sciences), Associate Professor, Sumy National Agrarian University, Sumy, Ukraine Holub M. G., Expert, Non-entrepreneurial Society "Association of Forest Certificationin Ukraine", Kyiv, Ukraine

Cherepovsky M. V., Student, Sumy National Agrarian University, Sumy, Ukraine

Methodological approaches and identification of high conservation value areas (in the eastern part of Sumy region forests)

Forest certification is one of the world's best-known voluntary environmental programs for sustainable forest management. Principle 9 "High conservation values" of voluntary forest certification under the FSC scheme provides for the need to take special measures for the identification and conservation of forest areas with existing high conservation values (HCVs). The identification of HCVs is an effective tool of forest certification, which encourages the forest enterprise to take into account the interests of a wide range of stakeholders, develop measures to preserve forest biodiversity and generally contribute to the greening of forest production. Modern methodological approaches to the identification of HCVs in forest areas, as well as their practical application in the forest fund of the state enterprise "Sumy Forestry" (northeastern part of Ukraine) were studied. Forest inventory materials, standards, manuals, reports, scientific publications were used. The research methods are generally accepted in FSC $₫$ forest certification. The division of HCVs into the categories listed in "FSC national standard of forestry system for Ukraine" (2020) was applied. The methodological approaches of many countries of the world to support forest ecosystems in areas with HCVs are considered. Particular attention was paid to the coverage of information related to forests that have undergone minimal human disturbance (primary forests, quasi-virgin areas, ancient forests). Intensive forestry leads to the loss of natural forests and related biodiversity. These negative trends in the state of biodiversity and the functioning of forest ecosystems require new initiatives. At the European Union level, the new initiative includes the concept of green infrastructure, which aims to ensure biodiversity, environmental sustainability and ecosystem services. Identification of HCV 1 Species diversity requires knowledge of the conservation status of plants and animals, HCV 3 Ecosystems and habitats - application of modern techniques and information on the search: ancient forests, plant communities from the "Green book of Ukraine", "National catalog of habitats of Ukraine", IBA- territories, etc. Finding HCV 5 Community needs and HCV 6 Cultural values requires stakeholder consultation. HCV 2 in Ukraine is not allocated. An important measure is the mapping of the contours of the areas with HCVs, a symbolic representation of their categories, the designation of valuable and rare habitats, and so on. The concept of HCVs can be considered a universal platform through which it is possible to identify the categories of those forest ecosystems that exist in conditions of potential danger. Many of these forests are still unprotected and need public attention.

Key words: forest certification, forest ecosystems, biodiversity, high conservation values (HCVs), Sumy region, Ukraine. 